https://doi.org/10.17816/MAJ191S156-58

\title{
THE ROLE OF SYMPATHIC AND PARASIMPATIC INNERVATION IN NEUROIMMULAR INTERACTIONS WITH EXTERNAL GUINETAL ENDOMETRIOSIS
}

\author{
A.E. Andreev ${ }^{1,2}$, A.O. Drobintseva ${ }^{1,2}$, V.O. Polyakova ${ }^{1,3}$ \\ ${ }^{1}$ Research Institute of Obstetrics, Gynecology and Reproductology named after D.O. Ott, Saint Petersburg, Russia; \\ ${ }^{2}$ Saint Petersburg State Pediatric Medical University, Saint Petersburg, Russia; \\ ${ }^{3}$ Saint Petersburg State University, Saint Petersburg, Russia

\section{РОЛЬ СИМПАТИЧЕСКОЙ И ПАРАСИМПАТИЧЕСКОЙ ИННЕРВАЦИИ В НЕЙРОИММУНЫХ ВЗАИМОДЕЙСТВИЯХ В ЭНДОМЕТРИИ ПРИ НАРУЖНОМ ГИНЕТАЛЬНОМ ЭНДОМЕТРИОЗЕ}

\author{
А.Е. Андреев ${ }^{1,2}$, А.О. Дробинцева ${ }^{1,2}$, В.О. Полякова ${ }^{1,3}$ \\ ${ }^{1}$ ФГБНУ «НИИ акушерства, гинекологии и репродуктологии им. Д.О. Отта», Санкт-Петербург; \\ ${ }^{2}$ ФГБОУ ВО «Санкт-Петербургский государственный педиатрический \\ медицинский университет», Санкт-Петербург; \\ ${ }^{3}$ Санкт-Петербургский государственный университет, Санкт-Петербург
}

Currently the study of the role of peripheral nervous system in control of inflammation in endometriosis and its involvement in the development of the chronic pain syndrome in this pathology is of relevance. The purpose of this work was to assess the reciprocal location of sympathetic and parasympathetic nerve fibers with external genital endometriosis at various stages of progression. The samples for the study were the endometrial biopsies of patients of reproductive age with external genital endometriosis of I-IV stage of the disease, with primary sterility $(n=20)$. The control group consisted of 3 patients $(n=5)$ who did not have any signs of endometriosis. Molecular markers were visualized using the immunohistochemical method. Antibodies to tyrosine hydroxylase (TH, 1:200, Abcam, USA) and PGP 9.5 (PGP 9.5, 1:1000, Abcam, USA) were used as primary antibodies. Alexa Fluor 488 (1:1000, Abcam, USA) and Alexa Fluor 647 (1:1000, Abcam) were used as secondary antibodies. The results were visualized with a confocal microscope (FluoView1000 (Olympus)). 3D shooting was used to assess the reciprocal location of the studied markers. As a result of this work, it was found that the expression of both of studied markers was detected in all samples. The obtained data can significantly increase the understanding of the functioning mechanisms of the neoneurogenesis processes in ectopic and eutopic tissue, thereby allowing an increase in the accuracy of the endometriosis diagnostic methods.

Keywords: endometriosis; tyrosine hydroxylase; PGP9.5; nerve fibers; confocal microscopy.

В настоящий момент актуально исследование роли периферической нервной системы в контроле воспалительных процессов при эндометриоидной болезни и ее вовлечение в развитии хронического болевого синдрома при данной патологии. Целью настоящей работы была оценка взаимного расположения симпатических и парасимпатических нервных волокон при наружном генитальном эндометриозе (НГЭ) на различных стадиях прогрессии. Образцами для исследования послужили биопсии эндометрия пациенток, репродуктивного возраста, с НГЭ на I-IV стадии заболевания, имеющих первичное бесплодие $(n=20)$. Группу контроля составили 3 пациентки $(n=5)$ не имеющие никаких признаков эндометриоза. Визуализация молекулярных маркеров производилась с применением иммуногоистохимического метода. В качестве первичных антител использовались антитела к тирозингидроксилазе (ТН, 1: 200, Abcam, США) и PGP 9.5 (PGP 9.5, $1: 1000$, Abcam, США). В качестве вторичных антител применялись Alexa Fluor 488 (1:1000, Abcam, США) и Alexa Fluor 647 (1: 1000, Abcam). Визуализация результатов производилась на конфокальном микроскопе (FluoView 1000 (Olympus)). Для оценки взаимного расположения исследуемых маркеров применялся режим 3D-съемки. В результате проведенной работы было установлено, что экспрессия обоих исследуемых маркеров выявлена во всех образцах. Полученные данные могут значительно увеличить понимание механизмов функционирования процессов неонейрогенеза в эктопической и эутопической ткани, позволив тем самым повысить точность методов диагностики эндометриоза.

Ключевые слова: эндометриоз; тирозингидроксилаза; PGP9.5; нервные волокна; конфокальная микроскопия.

Introduction. In gynecological morbidity patterns, there is a steady increase in the proportion of patients diagnosed with endometrial disease.
According to the official statistics of the Ministry of Health of the Russian Federation, the number of women with endometriosis increased by 
$13 \%$ from 2016 to 2017 [1]. According to federal guidelines for the management of patients with endometriosis, the disease has a number of features that determine its development: hormonal disorders, expressed primarily in a strong increase in the local concentration of estrogen and the development of progesterone resistance in endometriosis implants. Often inflammatory processes occur near the endometriosis implants that in conjunction with hormonal disorders activate processes of neoangiogenesis, leading to further growth of ectopic tissue with possible development of pain syndrome [2, 3]. Currently the study of the peripheral nervous system role in control of inflammatory processes in endometrial disease and its involvement in the development of the chronic pain syndrome in this pathology is of relevance. According to modern data, neoneurogenesis processes occur in endometriotic heterotopies, as a result of which heterotopies are innervated by fine nerve fibers [4]. The composition of these fibers is diverse, including sensory, sympathetic, and parasympathetic types. Each type of fiber performs its function and is expressed differently depending on the localization of endometriosis [5]. One of the key tasks is understanding of the involvement of nerve fibers in the development of endometriotic disease and determination of the expression of sympathetic and parasympathetic types of fibers with different types of endometriosis with a possibility to assess their relations and reciprocal localization. Recently the results were obtained using PGP 9.5 and tyrosine hydroxylase markers to assess sympathetic and parasympathetic nerve endings in various tissues of the human body. At the same time, PGP 9.5 verifies the parasympathetic nerve endings, and the tyrosine hydroxylase verifies the sympathetic ones [6]. The purpose of this work was to assess the reciprocal location, sympathetic and parasym- pathetic nerve fibers with external genital endometriosis at various stages of progression.

Materials and methods. The samples for the study were the endometrial biopsies of patients of reproductive age with external genital endometriosis of I-IV stage of the disease, with primary sterility $(n=20)$. The control group consisted of 3 patients $(n=5)$ who did not have any signs of endometriosis. Molecular markers were visualized using the immunohistochemical method. Antibodies to tyrosine hydroxylase (TH, 1:200, Abcam, USA) and PGP 9.5 (PGP 9.5, 1:1000, Abcam, USA) were used as primary antibodies. Alexa Fluor 488 (1:1000, Abcam, USA) and Alexa Fluor 647 (1:1000, Abcam) were used as secondary antibodies. The results were visualized with a confocal microscope (FluoView 1000 (Olympus)). 3D shooting was used to assess the reciprocal location of the studied markers.

Results and discussion. According to the results of the experiment, 3D images of the studied structures were constructed (Fig. 1).

As a result of this work, it was found that the expression of both of the studied markers was detected in all samples. In eutopic endometrium, the expression was predominantly localized in the stroma, near the endometrial glands, whereas in the ectopic endometrium, the expression was present in the glands themselves. It was also determined that the visualized markers belong to sympathetic or parasympathetic nerve endings. Thus, the proposed method of verification of sympathetic and parasympathetic fibers shows good results and can be used for further research.

The obtained data can significantly increase the understanding of the functioning mechanisms of the neoneurogenesis processes in ectopic and eutopic tissue, thereby allowing an increase in the accuracy of the endometriosis diagnostic methods.
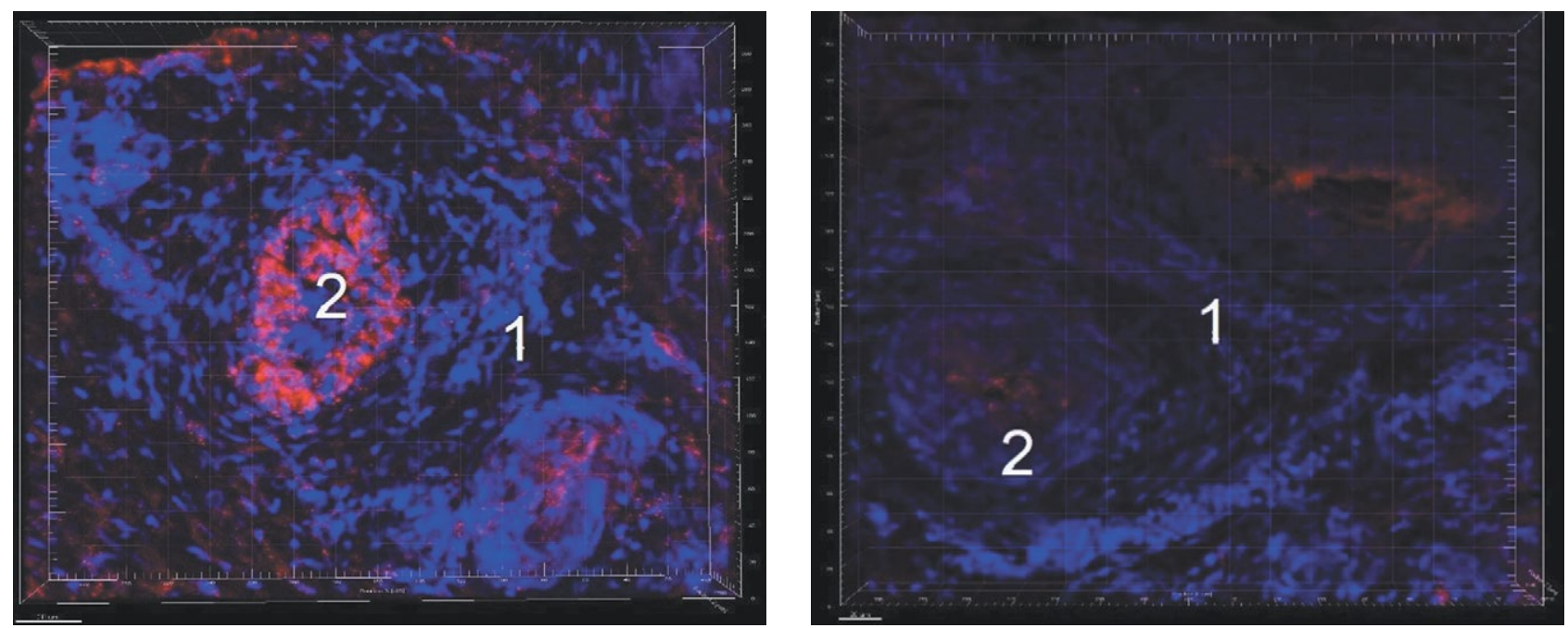

Fig. 1. Expression of PGP 9.5 (from the left) and tyrosine hydroxylase (from the right). Number 1 indicates the stroma, number 2 indicates the gland. Red color indicates the expression of the studied markers, blue color indicates the nuclei. Magnification $\mathrm{x} 40$ 


\section{References}

1. Министерство здравоохранения Российской Федерации, Департамент мониторинга, анализа и стратегического развития здравоохранения, ФГБУ «Центральный научно-исследовательский институт организации и информатизации здравоохранения» Минздрава: Заболеваемость взрослого населения России в 2016 году // Статистические материалы. Часть II. - М., 2016.

2. Ярмолинская М.И., Айламазян Э.К. Генитальный эндометриоз. Различные грани проблемы. СПб.: Эко-Вектор, 2017. - 615 с.

3. Адамян Л.В. и др. Эндометриоз: диагностика, лечение и реабилитация. Федеральные клинические рекомендации для ведения больных. - М., 2013. - 65 с.

4. Tokushige N, Markham R, Russell P, Fraser IS. Nerve fibres in peritoneal endometriosis. Hum Reprod. 2006;21(11):3001-3007.

5. Miller EJ, Fraser IS. The importance of pelvic nerve fibers in endometriosis. Womens Health (Lond). 2015;11(5):611-618.

6. Патент РФ №RU2657787C1. 15.06.2018. Иммуногистохимический способ выявления симпатических и парасимпатических структур на гистологических препаратах // Патент России RU2657787C1. 2018 / Inventor Е.И. Чумасов, Д.Э. Коржевский, Е.С. Петрова. 